Article

\title{
Inhibitory Activities of Dimeric Ellagitannins Isolated from Cornus alba on Benign Prostatic Hypertrophy
}

\author{
Dong-Hui Park ${ }^{1}$, Kwan-Hee Park ${ }^{1}$, Jun Yin ${ }^{1}$, Min-Ji Kim ${ }^{1}$, Seong-Eun Yoon ${ }^{1}$, Sun-Ho Lee ${ }^{1}$, Jun-Hyeok Heo ${ }^{1}$, \\ Hyun-Joo Chung ${ }^{2}$, Jin-Wook Kim ${ }^{2} \mathbb{D}$, Kyung-Mi Kim ${ }^{3}$ and Min-Won Lee ${ }^{1, * \mathbb{D}}$ \\ 1 Laboratory of Pharmacognosy and Natural Product Derived Medicine, College of Pharmacy, \\ Chung-Ang University, Seoul 06974, Korea; donghee9611@naver.com (D.-H.P.); \\ kwany1982@naver.com (K.-H.P.); yinjun89@naver.com (J.Y.); kam4256@naver.com (M.-J.K.); \\ blue6462@naver.com (S.-E.Y.); truman2001@naver.com (S.-H.L.); fifasthur@naver.com (J.-H.H.) \\ 2 Department of Urology, College of Medicine, Chung-Ang University, Seoul 06974, Korea; \\ hyunjoo1121@cau.ac.kr (H.-J.C.); jinwook@cau.ac.kr (J.-W.K.) \\ 3 Life Science Research Institute, NOVAREX.CO., Ltd., Cheongju 363885, Korea; kkm3507@novarex.co.kr \\ * Correspondence: mwlee@cau.ac.kr; Tel.: +82-2-820-5602; Fax: +82-2-816-7338
}

\section{check for} updates

Citation: Park, D.-H.; Park, K.-H.; Yin, J.; Kim, M.-J.; Yoon, S.-E.; Lee, S.-H.; Heo, J.-H.; Chung, H.-J.; Kim, J.-W.; Kim, K.-M.; et al. Inhibitory Activities of Dimeric Ellagitannins Isolated from Cornus alba on Benign Prostatic Hypertrophy. Molecules 2021, 26, 3446. https://doi.org/ $10.3390 /$ molecules 26113446

Academic Editor: Jorge A.

R. Salvador

Received: 30 April 2021

Accepted: 1 June 2021

Published: 6 June 2021

Publisher's Note: MDPI stays neutral with regard to jurisdictional claims in published maps and institutional affiliations.

Copyright: (c) 2021 by the authors. Licensee MDPI, Basel, Switzerland. This article is an open access article distributed under the terms and conditions of the Creative Commons Attribution (CC BY) license (https:// creativecommons.org/licenses/by/ $4.0 /)$.

\begin{abstract}
Benign prostatic hypertrophy (BPH) is an intractable chronic inflammatory disease. We studied the efficacy of two ellagitannins, namely camptothin B (1) and cornusiin A (2) that were isolated from Cornus alba (CA) for the treatment of $\mathrm{BPH}$, which is a common health issue in older men. The ellagitannins ( $\mathbf{1}$ and $\mathbf{2}$ ) were evaluated on its inhibitory activities of the enzyme $5 \alpha$-reductase and tumor necrosis factor (TNF)- $\alpha$, its interleukin (IL)-1 $\beta$, IL-6, and IL-8 production, and its antiproliferation and apoptosis induction in prostate cells that show hypertrophy (RWPE-1 cell). In inhibition of $5 \alpha$-reductase, the ellagitannins ( $\mathbf{1}$ and 2 ) showed potential effects, compared to the positive control, finasteride. In the case of IL- $1 \beta$, IL-6, IL- 8 , and TNF- $\alpha, \mathbf{1}$ and 2 showed good inhibitory effects as compared to the control group treated with LPS. The ellagitannins (1 and 2) were also shown to inhibit proliferation of, and induce apoptosis in, the RWPE-1 cell. These results suggest that the ellagitannins ( $\mathbf{1}$ and $\mathbf{2}$ ) may be good candidates for the treatment of $\mathrm{BPH}$.
\end{abstract}

Keywords: dimeric ellagitannin; Cornus alba; benign prostatic hypertrophy (BPH)

\section{Introduction}

Benign prostatic hypertrophy (BPH), a type of overgrowth of the prostate tissue, is a common problem in older men. Prostate hyperplasia is closely related to aging and male hormones, and is a progressive disease that does not directly affect life with increase in age, but lowers urinary symptoms, such as residual, empty, thin, night, and intermittent urination along with mental, social, sexual problems [1-3]. Studies have reported that prostatic growth begins at age 30, with BPH affecting approximately $50 \%$ of men aged 50 and $70 \%$ of men older than $80[4,5]$. The cause of BPH is unclear, however, studies have suggested that the common factors that might induce the development of BPH are hormonal alterations, ageing, and inflammation [6,7]. The main treatments for BPH are medications and surgery. However, few men have symptoms or other problems that are severe enough to require surgical treatment. The medications used to treat $\mathrm{BPH}$ include alpha-blockers and 5-alpha reductase inhibitors (5-ARI) [8]. Alpha blockers treat the symptoms of BPH by relaxing the smooth muscle tissue in the prostate and bladder to help the urine flow out. It has no effect on prostate growth through its mechanism of action, and can quickly heal symptoms of the lower urinary tract [9]. BPH is caused by the influence of dihydrotestosterone (DHT), which is known to be a testosterone derivative with a high affinity for androgen receptors [8]. In the case of 5-ARI, the size of the prostate is reduced by inhibiting the production of DHT. Unlike the alpha blocker, which improves relatively quickly, 5-ARI takes a long time to contract the prostate [10]. 
Cornus alba (CA), is a species of Cornaceae, native to Siberia, Northern China, and Korea. It is a deciduous shrub that can grow to $3 \mathrm{~m}$ high, like a small tree. The barks and leaves of CA were used as folk herbal medicine for the treatment of inflammation and hemolysis. CA bark is also used in hemoptysis of pulmonary tuberculosis, and the root is used for fever and cold [11,12]. Cornus species are known to have antioxidant, anti-inflammatory, and anti-cancer biological activities [13,14].

In our previous work, we studied the antiproliferative effects of new dimeric ellagitannin from Cornus alba in prostate cancer cells, including apoptosis-related S-phase arrest [15]. This study was performed to prove that ellagitannins (1 and $\mathbf{2})$, which were isolated from CA, can be used as treatment for BPH, through the evaluations of cytokines IL-6, IL-8, IL-1 $\beta$, TNF- $\alpha$, anti-proliferative effect on BPH cell line, flow cytometry analysis of apoptosis, and $5 \alpha$-reductase inhibition activity.

\section{Result}

\subsection{Phytochemicals from Cornus alba}

We isolated several hydrolysable tannins from CA and selected two major ellagitannins (1 and $\mathbf{2}$ ) for this study (Figure 1) [16].

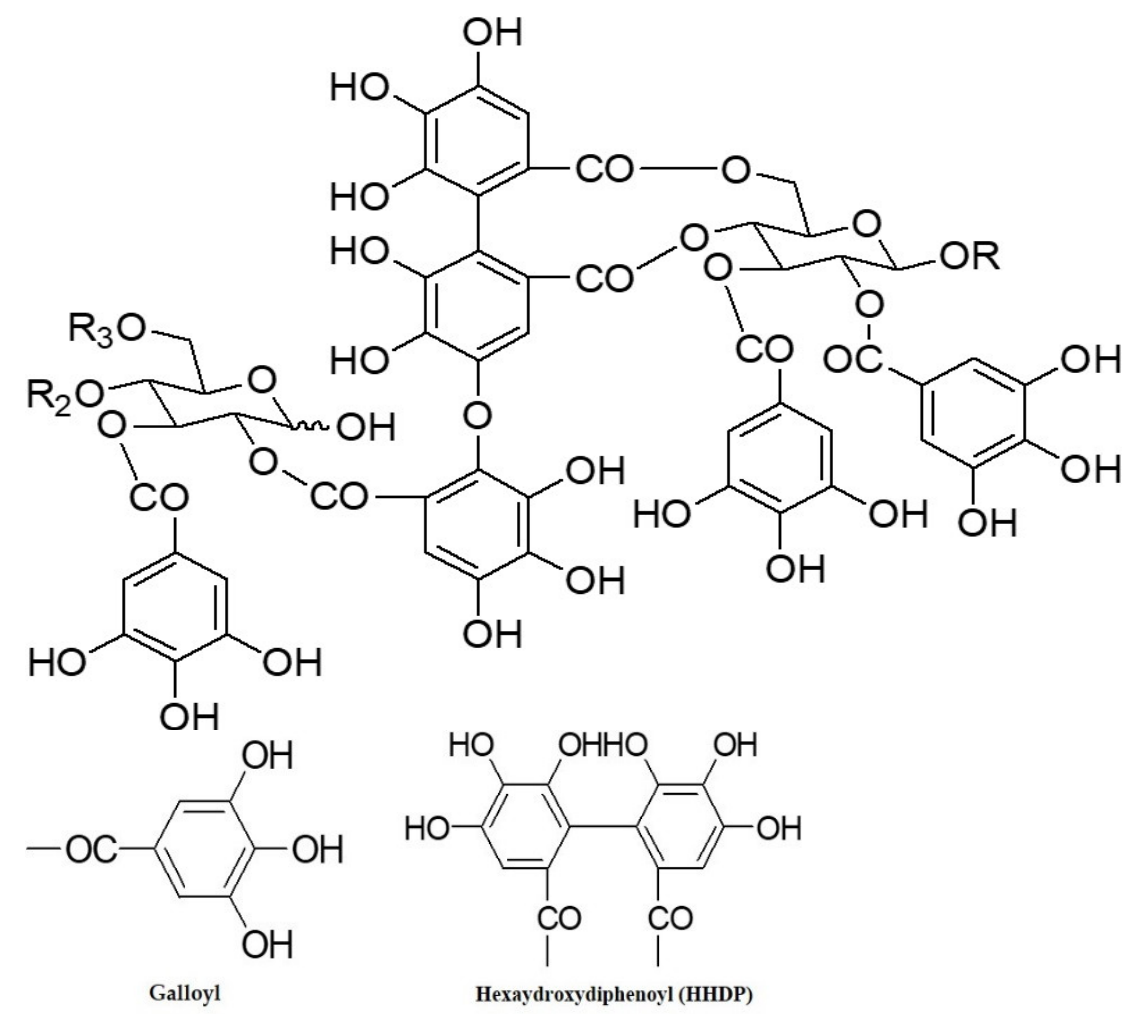

$1 \mathrm{R}_{1}$ : -Galloyl $\mathrm{R}_{2} / \mathrm{R}_{3}$, :-HHDP

$2 \mathrm{R}_{1}$ : - $\mathrm{H}, \quad \mathrm{R}_{2} / \mathrm{R}_{3}$, :-HHDP

Figure 1. The structures of compounds $\mathbf{1}$ and $\mathbf{2}$ isolated from Cornus alba.

\subsection{Inhibition of Cytokines Production}

Compounds 1 and 2 were shown to potently inhibit the production of cytokines IL-6 and 8 , which are autocrine growth factors that play a key role in inducing the development of hyperplasia of the prostate in BPH patients and in prostate cancer cells (Figures 2 and 3) [17,18]. 


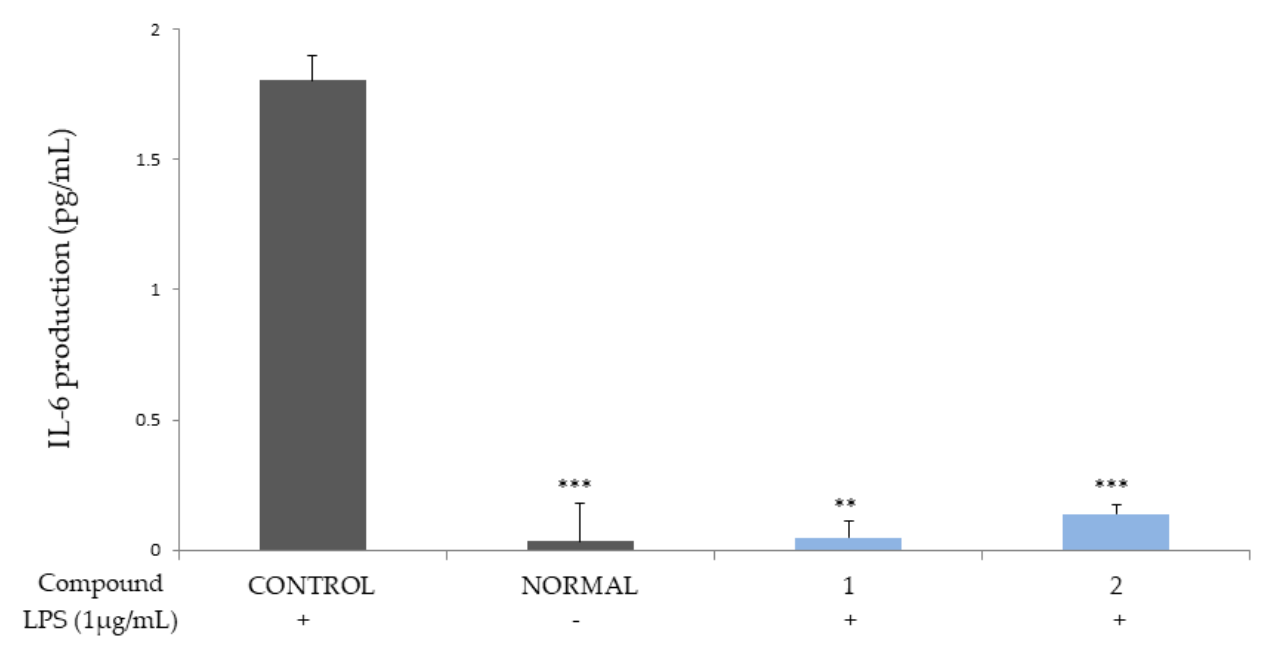

Figure 2. Inhibitory activities of compounds 1 and 2 on IL-6 production in the THP-1 macrophage cell. Control, compounds 1 and 2 were added LPS $(1 \mu \mathrm{g} / \mathrm{mL})$. Normal was not added LPS. Values are expressed as the means \pm standard deviation (SDs) from triplicate measurements. ${ }^{*} p<0.05,{ }^{* *} p<0.01$, and ${ }^{* * *} p<0.001$.

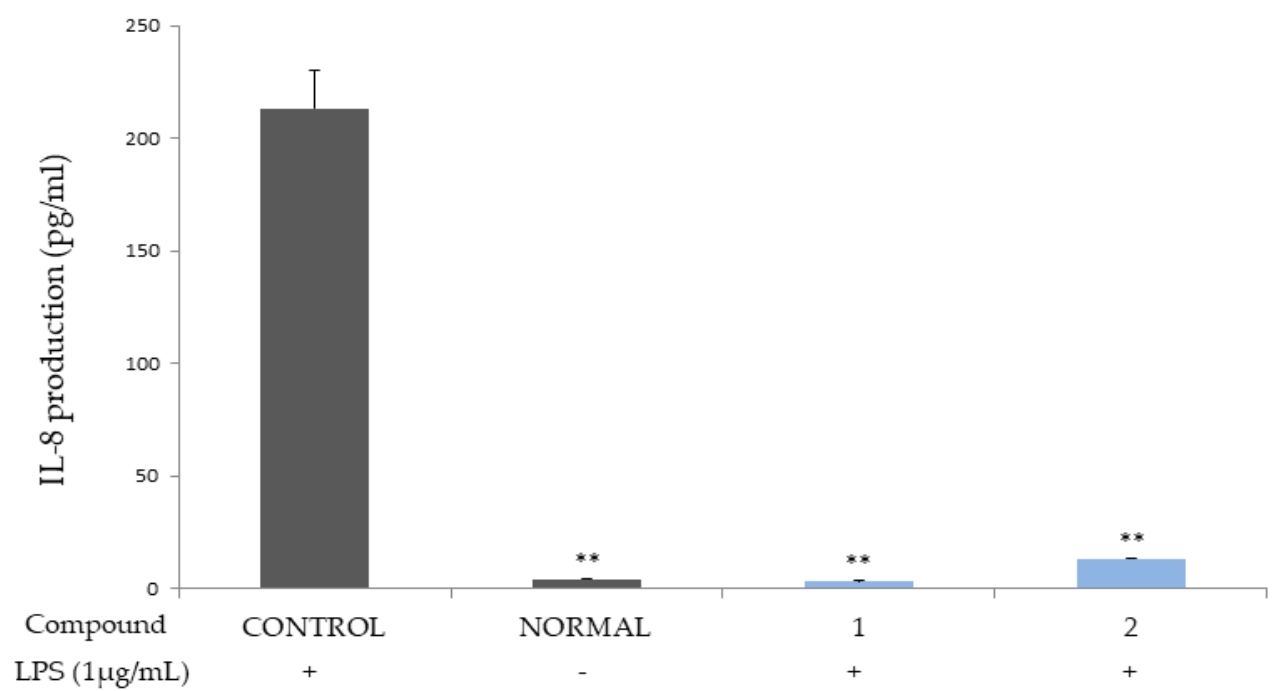

Figure 3. Inhibitory activities of compounds 1 and $\mathbf{2}$ on IL-8 production in THP-1 macrophage cell. Control, compounds $\mathbf{1}$ and 2 were added LPS $(1 \mu \mathrm{g} / \mathrm{mL})$. Normal was not added LPS. Values are expressed as the means \pm standard deviations (SDs) from triplicate measurements. ${ }^{*} p<0.05$, and ${ }^{* *} p<0.01$.

The ellagitannins (1 and $\mathbf{2})$ were also shown to induce a potent decrease in the productions of IL-1 $\beta$ and TNF- $\alpha$ (Figures 4 and 5), which are major cytokines involved in systemic inflammation, as well as in stimulating the acute phase reaction and biological markers of prostatic secretion, as indicators of prostatic inflammation in chronic prostatitis [19-21]. 


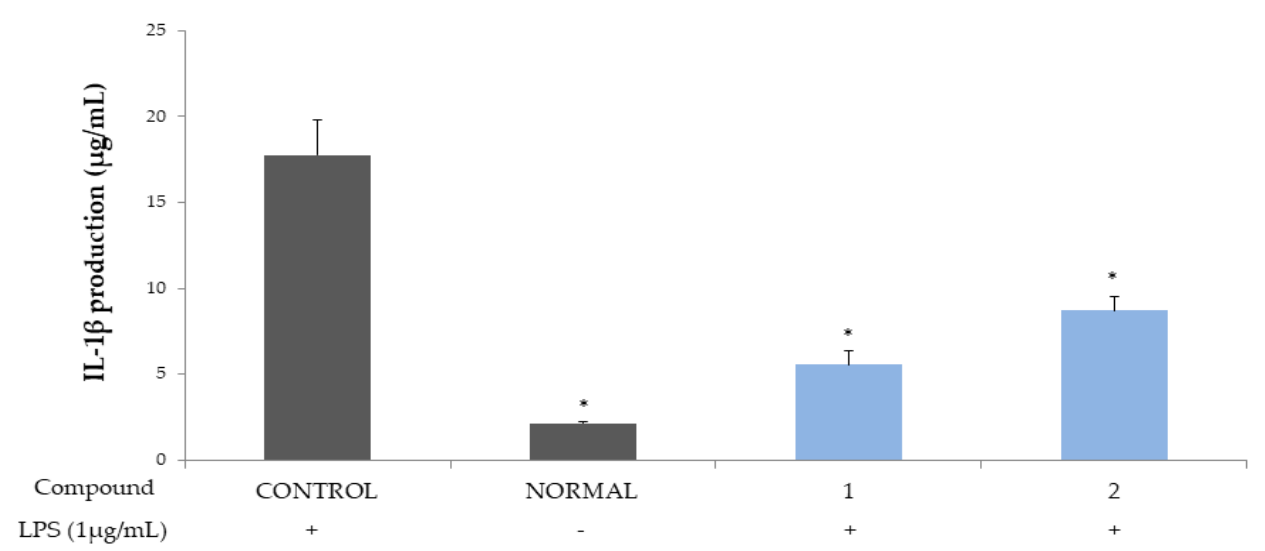

Figure 4. Inhibitory activities of compounds 1 and 2 on IL-1 $\beta$ production in the THP- 1 macrophage cell. Control, compounds 1 and 2 were added LPS $(1 \mu \mathrm{g} / \mathrm{mL})$. Normal was not added LPS. Values are expressed as the mean \pm standard deviations (SDs) from triplicate measurements. ${ }^{*} p<0.05$.

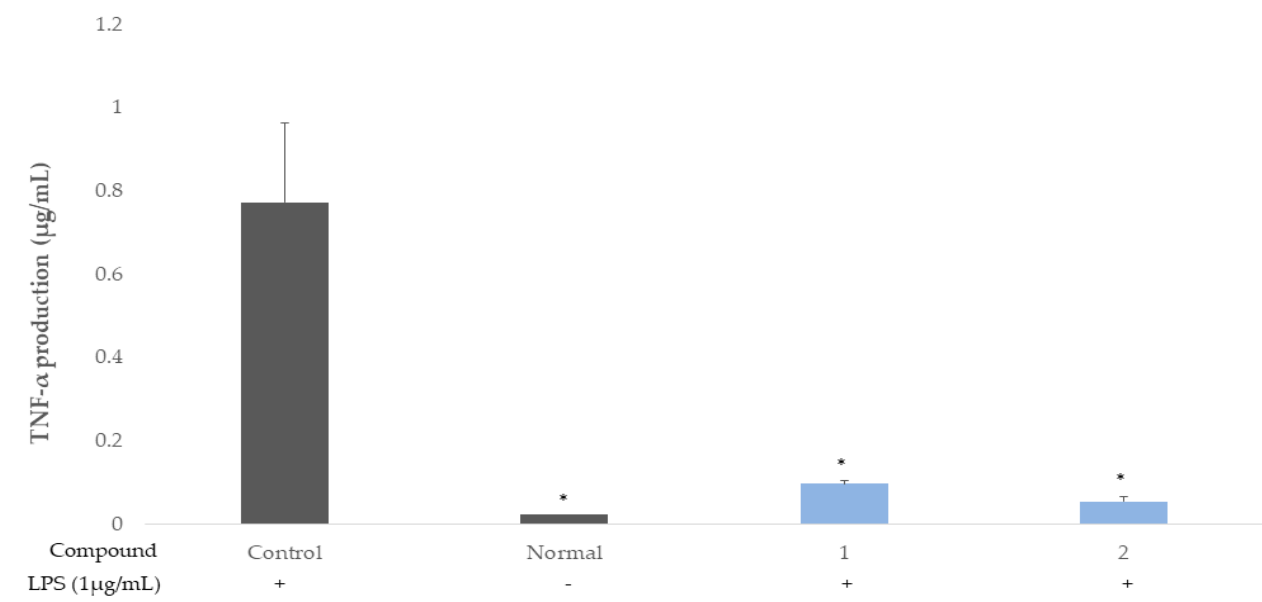

Figure 5. Inhibitory activities of $\mathbf{1}$ and $\mathbf{2}$ on TNF- $\alpha$ production in the THP-1 macrophage cell. Control, compounds $\mathbf{1}$ and $\mathbf{2}$ were added LPS $(1 \mu \mathrm{g} / \mathrm{mL})$. Normal was not added LPS. Values are expressed as means \pm standard deviations (SDs) from triplicate measurements. ${ }^{*} p<0.05$.

\subsection{Anti-Proliferative Effect on BPH Cell Line}

The anti-proliferative effect of the compounds on the BPH cell line (RWPE-1 cell) was measured via an MTT assay, after the cells were treated with the compounds at concentrations between $6.25-100 \mu \mathrm{M}$, for $24 \mathrm{~h}$. The ellagitannins ( 1 and 2 ) were shown to have anti-proliferative activities with half maximal inhibitory concentrations $\left(\mathrm{IC}_{50}\right)$ of $3.38 \pm 0.71$ and $1.54 \pm 0.21$, respectively.

\subsection{Flow Cytometry Analysis of Apoptosis}

Phosphatidylserine (PS) is a phospholipid that exists inside the cell membrane in normal cells, and is exposed to the outside of the cell membrane, when apoptosis progresses [22]. PS binds to a specific protein called Annexin V. By combining a fluorescent substance here, the degree of apoptosis of cells can be checked through flow cytometry [23]. In addition, using a propidium iodide (PI) fluorescent dye that passes through the cell membrane of dead cells and binds to DNA, it is possible to identify early apoptosis, late apoptosis, and even necrosis. In Figures 6 and 7, the uniform viability, which shows the lower left part, represents a living normal cell, and both Annexin V and PI are observed as negative. The ellagitannins (1 and 2 ) represent $15.14 \%$ and $8.39 \%$, respectively. Early apoptosis, indicating the lower right part, was found to be positive only for Annexin V, with $6.06 \%$ and $7.95 \%$ of $\mathbf{1}$ and $\mathbf{2}$, respectively. Late apoptosis, which indicates the upper right 
part, indicates cells that have died due to apoptosis progression. Additionally, because the cell membrane collapses, both Annexin V and PI are positive and the ellagitannins (1 and 2) were $43.00 \%$ and $74.43 \%$, respectively. Necrosis, which represents the upper left part, is a cell necrosis or pathologically dead part, PI is positive because PS is not exposed to the extracellular membrane, but Annexin $\mathrm{V}$ is negative and the ellagitannins (1 and 2) represent $35.79 \%$ and $9.24 \%$, respectively.

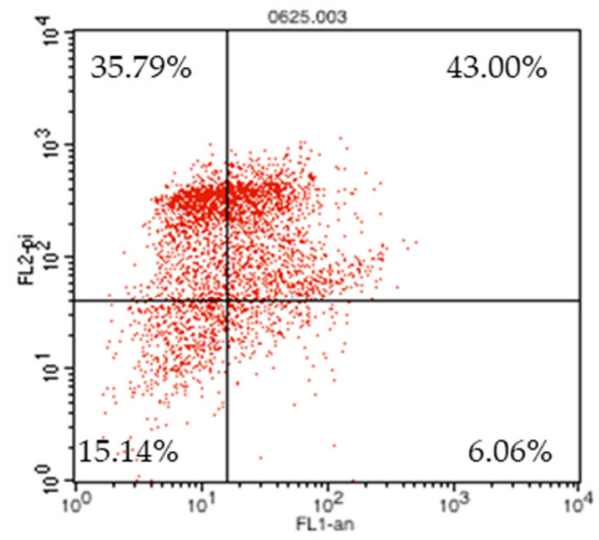

(a)

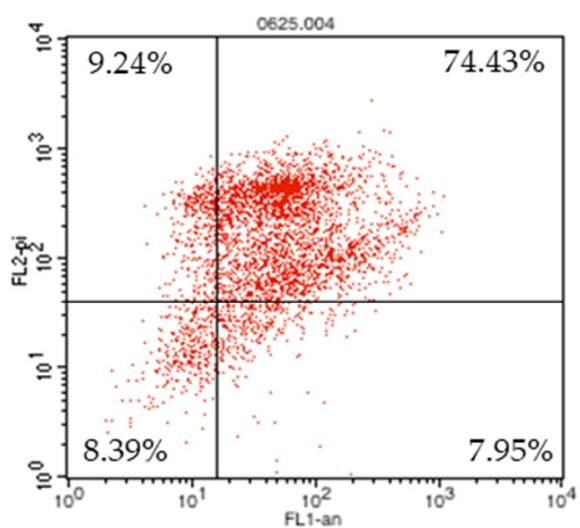

(b)

Figure 6. Flow cytometry analysis of apoptosis via annexin V/PI dual staining in the RWPE-1 cell. (a) Flow cytometry analysis of apoptosis treated with compound 1. (b) Flow cytometry analysis of apoptosis treated with compound 2.

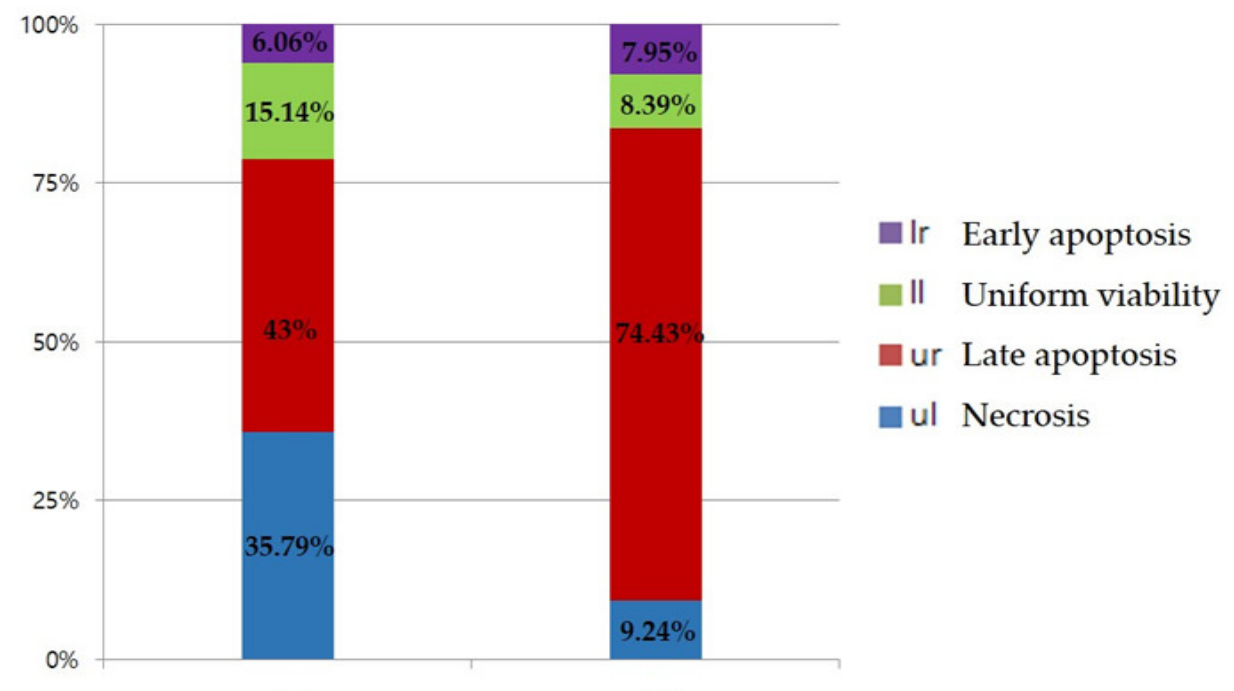

(a)

(b)

Figure 7. Flow cytometry (FACS) analysis of compounds $\mathbf{1}$ and 2. (a) represents compound $\mathbf{1}$ and (b) represents compound 2 .

Cells were incubated with the compounds 1 and 2 at a concentration of $25 \mu \mathrm{M}$ for $24 \mathrm{~h}$, in a complete medium. The percentage of cell in each quadrant is indicated (lower leftnormal, lower right-apoptosis, upper right-late apoptosis, and upper left-necrosis)

The percentage of cells in the upper left (necrotic cells) and the upper right (late apoptotic cells) quadrants. The percentage of cells in the lower right (early apoptotic cells), and lower left (viable cells) portions of the histogram was calculated for comparison.

\subsection{5 $\alpha$-Reductase Inhibition Activity}

The reduction of the level of DHT via the inhibition of $5 \alpha$-reductase might be a good way to treat BPH [24]. As such, $5 \alpha$-reductase and testosterone were mixed with the 
samples and the concentration of testosterone was detected by HPLC. Compared to the samples treated with the control (finasteride), the ellagitannins (1 and 2 ) showed potential $5 \alpha$-reductase inhibitory activity (Figure 8 ).

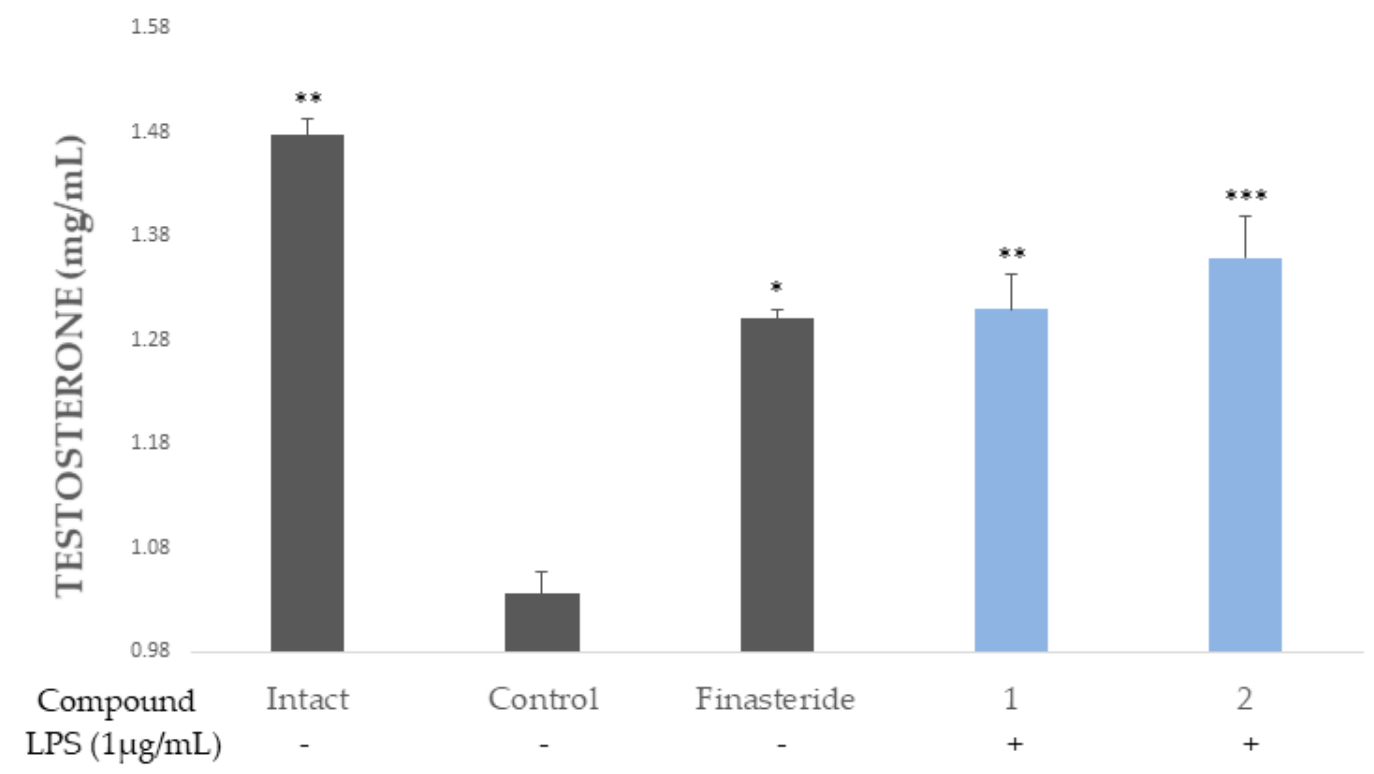

Figure 8. Compounds 1 and 2 inhibit $5 \alpha$-reductase activity. Values are expressed as the means \pm standard deviations (SDs) from the triplicate measurements. ${ }^{*} p<0.05,{ }^{* *} p<0.01,{ }^{* * *} p<0.001$.

\section{Discussion}

There is ongoing research that aims to find a therapeutic agent for prostate disease using natural products through evaluation of the pharmacological properties of antiproliferative, antioxidant, and anti-inflammatory substances [25].

In this study, the ellagitannins (1 and $\mathbf{2}$ ) isolated from CA were evaluated for their inhibitory activities on cytokines IL-6, IL-8, IL- $1 \beta$, and TNF- $\alpha$; their anti-proliferative effect on the RWPE- 1 cell; flow cytometry analysis of apoptosis; and $5 \alpha$-reductase inhibition activity.

The overexpression of proinflammatory cytokines, such as interferon (IFN) $-\gamma$ and IL-17, in the BPH tissue, induces the production of IL-6 and IL-8 [20]. It is reported that IL-1 $\beta$ and tumor necrosis factor (TNF)- $\alpha$ were shown to be elevated in $\mathrm{BPH}$ patients [16].

The ellagitannins (1 and $\mathbf{2}$ ) potently reduced the productions of the cytokines, IL-6 and IL- 8 (Figures 2 and 3), and IL-1 $\beta$ and TNF- $\alpha$ (Figures 4 and 5).

The ellagitannins ( $\mathbf{1}$ and $\mathbf{2}$ ) were shown to have anti-proliferative activities on the $\mathrm{BPH}$ cell line (RWPE- 1 cell, IC50 of $3.38 \pm 0.71$ and $1.54 \pm 0.21$, respectively).

Their effect on apoptosis were then further analyzed using an Annexin V-FITC (Annexin V) and propidium iodide (PI) staining assay. Annexin V, a Ca ${ }^{2+}$-dependent phospholipid (PS)-binding protein, binds to the exposed PS at the surface of the apoptotic cell membrane [26,27], while PI, a DNA staining agent, cannot cross the intact plasma membrane of live cells [28]. The Annexin V+/PI- cells were considered to be early apoptotic cells, while the Annexin V+/PI+ cells were considered to be late apoptotic cells. The results indicated that 1 and 2 exhibited potent late apoptosis activity. In addition, the ratio of necrosis was lower than that of $\mathbf{2}$ to $\mathbf{1}$, and the overall apoptosis rate was higher, so it could be said that $\mathbf{2}$ was more effective than $\mathbf{1}$ (Figures 6 and 7).

The enzyme $5 \alpha$-reductase catalyzed the reduction of testosterone to dihydrotestosterone (DHT), which could bind to the androgen receptor (AR). The AR, which is activated by binding to the androgenic hormones, testosterone, and DHT, regulates gene expression via the DNA-binding transcription factors [29]. Moreover, DHT has a stronger affinity for human AR than testosterone and adrenal androgens [30,31]. The results revealed that the ellagitannins (1 and $\mathbf{2}$ ) have potent inhibition of $5 \alpha$-reductase. 


\section{Materials and Methods}

\subsection{Compounds}

CA $(5.7 \mathrm{~kg}$ ) was collected at the Korea National Arboretum (Pocheon, Korea). The CA samples $(5.7 \mathrm{~kg}$ ) were pulverized and extracted with $80 \%$ acetone at room temperature to obtain the CA extract (463 g). Then, the extraction and its subfraction ( $356 \mathrm{~g}$ ) were separated via repeated column chromatography. Next, the samples were dissolved in water and filtered through a Celite 545 (Duksan Pure Chemical, Ansan, Korea) filter. After this, $356 \mathrm{~g}$ of a water-soluble fraction was obtained together with $89 \mathrm{~g}$ of water-insoluble residue. Only $243 \mathrm{~g}$ of the water-soluble fraction was loaded onto a Sephadex LH-20 column $(15 \times 100 \mathrm{~cm})$, equilibrated with water. After the column was eluted with a watermethanol gradient system and washed with $60 \%$ acetone, 14 fractions were obtained. Fraction $13(31.6 \mathrm{~g})$ was loaded onto an MCI CHP 20P column $(5 \times 60 \mathrm{~cm})$, with a watermethanol gradient system, and five subfractions were obtained. Afterwards, fraction 13-2 was loaded onto a Daisogel column $(3 \times 50 \mathrm{~cm})$, with a water $20 \%$ methanol gradient in a medium pressure liquid Chromatography (MPLC) system ( $5 \mathrm{~mL} / \mathrm{min}, 280 \mathrm{~nm})$. It was further separated by column chromatography on the Sephadex LH-20 column $(10 \times 80 \mathrm{~cm})$, using a water-methanol $60 \%$ acetone gradient system. As a result, cornusiin A $(2,1.2 \mathrm{~g})$ was obtained. Fraction 13-3 was loaded onto a Sephadex LH-20 column $(2.5 \times 50 \mathrm{~cm})$, with a water-methanol $60 \%$ acetone gradient system, and was further separated by column chromatography on the MCI CHP20P column $(5 \times 60 \mathrm{~cm})$, using a water-methanol gradient system. This resulted in three additional sub-fractions. Fraction 13-3-1 was then separated by column chromatography using a Toyopearl HW- 40 column $(2.5 \times 50 \mathrm{~cm})$, with a $70 \%$ methanol- $70 \%$ acetone $(10: 0 \rightarrow 7: 3)$ gradient, which yielded camptothin $B(1,815 \mathrm{mg})$.

\subsubsection{Camptothin B (1)}

The product was an amorphous brown powder. Structural data were as follows: LRFAB-MS $m / z: 1721[\mathrm{M}-\mathrm{H}]^{(-)}$; $\mathrm{CD}(\mathrm{MeOH}):[\theta]_{223} 16.13,[\theta]_{259} 3.18,[\theta]_{280} 6.36$;

${ }^{1} \mathrm{H}-\mathrm{NMR}\left(600 \mathrm{MHz}\right.$, Acetone- $\left.d_{6}+\mathrm{D}_{2} \mathrm{O}\right): \delta 3.73-3.96$ (each br d, $J=13.2, \mathrm{H}-6 \mathrm{~b}$ of each two form), 4.14, 4.48, 4.59-4.65 (br dd, $J=6.0,9.6 \mathrm{~Hz}, \mathrm{H}-5_{\mathrm{R}}$ and $\mathrm{H}-5_{\mathrm{L}}$ of each two form), $4.50\left(1 \mathrm{H}, J=7.8 \mathrm{~Hz}, \mathrm{H}-1_{\mathrm{L}}\right.$ of $\beta-\beta$ form), 5.01 5.34 (complicated peaks, $\mathrm{H}-2_{\mathrm{R}}$ and $2_{\mathrm{L}}, \mathrm{H}-4_{\mathrm{R}}$ and $\mathrm{H}-4_{\mathrm{L}}, \mathrm{H}-6 \mathrm{a}_{\mathrm{R}}$ and $\mathrm{H}-6 \mathrm{a}_{\mathrm{L}}$ of each two form $), 5.35\left(0.5 \mathrm{H}, \mathrm{d}, J=3.6 \mathrm{~Hz}, \mathrm{H}-1_{\mathrm{L}}\right.$ of $\alpha-\beta$ form), $5.46 \sim 5.85$ (each $\mathrm{t}, J=9.6 \mathrm{~Hz}, \mathrm{H}-3_{\mathrm{R}}$ and $\mathrm{H}-3_{\mathrm{L}}$ of each two from), $6.18(0.5 \mathrm{H}, \mathrm{t}, J=8.4 \mathrm{~Hz}$, $\mathrm{H}-1_{\mathrm{R}}$ of $\alpha-\beta$ form ), 6.19 (1H, s, val $\mathrm{H}_{\mathrm{B}}$ of $\beta-\beta$ form), 6.21 (0.5H, s, val $\mathrm{H}_{\mathrm{B}}$ of $\alpha-\beta$ form), 6.22 $\left(1 \mathrm{H}, \mathrm{t}, J=8.4 \mathrm{~Hz}, \mathrm{H}-1_{\mathrm{R}}\right.$ of $\beta-\beta$ form $), 6.51(1 \mathrm{H}, \mathrm{s}, \mathrm{HHDP}$ of $\beta-\beta$ form $), 6.53(0.5 \mathrm{H}, \mathrm{s}, \mathrm{HHDP}$ of $\alpha-\beta$ form), $6.60\left(0.5 \mathrm{H}\right.$, s, val $\mathrm{H}_{\mathrm{A}}$ of $\alpha-\beta$ form $), 6.53(0.5 \mathrm{H}, \mathrm{s}, \mathrm{HHDP}$ of $\alpha-\beta), 6.60(0.5 \mathrm{H}, \mathrm{s}$, val $\mathrm{H}_{\mathrm{A}}$ of $\alpha-\beta$ form), 6.63 (1H, s, val $\mathrm{H}_{\mathrm{A}}$ of $\beta-\beta$ form), 6.65 (0.5, s, HHDP of $\alpha-\beta$ form), 6.68 (1H, s, HHDP of $\beta-\beta$ form), 6.85 (1H, s, galloyl H-2, 6 of $\beta-\beta$ form), $6.92(0.5 \mathrm{H}$, s, galloyl $\mathrm{H}-2,6$ of $\alpha-\beta$ form), 7.00-7.14 (each s, $3 \times$ galloyl $\mathrm{H}-2,6$; val $\mathrm{H}_{\mathrm{C}}$ of each two from).

${ }^{13} \mathrm{C}-\mathrm{NMR}\left(150 \mathrm{MHz}\right.$, Aceotone- $\left.d_{6}+\mathrm{D}_{2} \mathrm{O}\right): \delta 62.5-63.0\left(\mathrm{C}-6_{\mathrm{L}}\right.$ and $\mathrm{C}-6_{\mathrm{R}}$ of each two form), 66.1 (C-5 $5_{L}$ of $\alpha-\beta$ form), $70.0-71.0\left(C-4_{L}\right.$ and $C-4_{R}$ of each two form; $C-3_{L}$ of $\alpha-\beta$ form, $C-5_{R}$ of $\beta-\beta$ form, $C-5_{L}$ of $\beta-\beta$ form), 71.9-73.2 (C-2 $L_{L}$ and $C-2_{R}$ of each two form; $C-3_{R}$ of $\alpha-\beta$ form, $C-3_{R}$ of $\beta-\beta$ form, $C-3_{L}$ of $\beta-\beta$ form), 90.1 (C-1 $1_{L}$ of $\alpha-\beta$ form), $92.6-92.8$ $\left(C-1_{R}\right.$ of $\alpha-\beta$ form, $C-1_{R}$ of $\beta-\beta$ form, $C-1_{L}$ of $\beta-\beta$ form), 104.0 (val C-3'), 106.9(-)107.2 (val C-3, HHDP C-3, HHDP C-3'), 109.0-109.9 (gal C-2 gal C-6; val C-6"'), 113.0-115.2 (HHDP C-1, HHDP C-1'; val C-1, val C-1', valC-1') , 118.7-119.7 (gal C-1), 124.1-125.7 (HHDP C-2, HHDP C-2'; val C-2, val C-2'), 135.0-136.6 (HHDP-5, HHDP-5'; val C-5, val C-5', val-2"'), 138.3-138.6 (gal C-4), 138.9-139.6 (val C- $3^{\prime \prime}$, val C-4" $\left.{ }^{\prime \prime}\right), 142.2-142.5$ (val C-5"), $143.5-145.1$ (gal C-3, gal C-5; HHDP C-4, HHDP C-4', HHDP C-6, HHDP C-6'; val C-4, val C-6, val C-6'), 145.7-146.7 (val C-4'), 163.9-167.7 (gal C-7; HHDP C-7, HHDP C-7'; val C-7, valC-7"').

\subsubsection{Cornusiin A (2)}

The product was an amorphous yellowish white powder. Structural data were as follows:

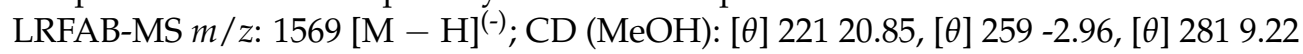


${ }^{1} \mathrm{H}-\mathrm{NMR}\left(600 \mathrm{MHz}\right.$, Acetone- $\left.d_{6}+\mathrm{D} 2 \mathrm{O}\right): \delta 3.76-3.96\left(\right.$ each br d, $J=13.2 \mathrm{~Hz}, \mathrm{H}-6 \mathrm{~b}_{\mathrm{L}}$ and $\mathrm{H}-6 \mathrm{~b}_{\mathrm{R}}$ of each four form), 4.17-4.24, 4.42-4.45 (each br dd, $J=6.6,10.2 \mathrm{~Hz}, \mathrm{H}-5_{\mathrm{R}}$ of $\alpha-\beta$ form, $H-5_{L}$ of $\beta-\alpha$ form, $H-5_{R}$ of $\beta-\beta$ form, $H-5_{L}$ of $\beta-\beta$ form $), 4.48\left(d, J=7.8, H-1_{L}\right.$ of $\beta-\beta$ form), 4.52 (d, $J=7.8 \mathrm{H}-1_{\mathrm{L}}$ of $\beta-\alpha$ form), 4.60-4.65, 4.73-4.82 (each br dd, $J=6.6,10.2 \mathrm{~Hz}$, $\mathrm{H}-5_{\mathrm{R}}$ of $\alpha-\alpha$ form, $\mathrm{H}-5_{\mathrm{L}}$ of $\alpha-\alpha$ of form, $\mathrm{H}-5_{\mathrm{L}}$ of $\alpha-\beta$ form, $\mathrm{H}-5_{\mathrm{R}}$ of $\beta-\alpha$ form), $5.03-5.11$ (complicated peaks, $\mathrm{H}-2_{\mathrm{R}}$ of $\alpha-\alpha$ form, $\mathrm{H}-2_{\mathrm{L}}$ of $\alpha-\alpha$ form, $\mathrm{H}-2_{\mathrm{L}}$ of $\alpha-\beta$ form, $\mathrm{H}-2_{\mathrm{R}}$ of $\beta-\alpha$ form; $\mathrm{H}-4_{\mathrm{L}}$ and $\mathrm{H}-4_{\mathrm{R}}$ of each four form), 5.20-5.27, 5.43-5.52 (complicated peaks, $\mathrm{H}-6 \mathrm{a}_{\mathrm{L}}$ and $H-6 a_{R}$ of each four form; $H-3_{R}$ of $\alpha-\beta$ form, $H-3_{L}$ of $\beta-\alpha$ form, $H-3_{R}$ of $\beta-\beta$ form, $H-3_{L}$ of $\beta-\beta$ form), 5.15 (each $d, J=8.4 \mathrm{~Hz}, \mathrm{H}-1_{\mathrm{R}}$ of $\alpha-\beta$ form, $\mathrm{H}-1_{\mathrm{R}}$ of $\beta-\beta$ form), $5.13-5.18$ (each $\mathrm{dd}, J=8.4,9.6 \mathrm{~Hz}, \mathrm{H}-2_{\mathrm{R}}$ of $\alpha-\beta$ form, $\mathrm{H}-2_{\mathrm{L}}$ of $\beta-\alpha$ form, $\mathrm{H}-2_{\mathrm{R}}$ of $\beta-\beta$ form, $\mathrm{H}-2_{\mathrm{L}}$ of $\beta-\beta$ form), 5.37-5.39 (each $\mathrm{d}, J=3.6 \mathrm{~Hz}, \mathrm{H}-1_{\mathrm{L}}$ of $\alpha-\beta, \mathrm{H}-1_{\mathrm{L}}$ of $\alpha-\alpha$ form), $5.53(\mathrm{~d}, J=3.6 \mathrm{~Hz}$, $\mathrm{H}-1_{\mathrm{R}}$ of $\alpha-\alpha$ form), $5.56\left(\mathrm{~d}, J=3.6 \mathrm{~Hz}, \mathrm{H}-1_{\mathrm{R}}\right.$ of $\beta-\alpha$ form), 5.69 5.85 (each $\mathrm{t}, J=9.6 \mathrm{~Hz}, \mathrm{H}-3_{\mathrm{R}}$ of $\alpha-\alpha$ form, $H-3_{L}$ of $\alpha-\alpha$ form, $H-3_{L}$ of $\alpha-\beta$ form, $H-3_{R}$ of $\beta-\alpha$ form), 6.21, 6.22, 6.23, 6.26 (each s, val $\mathrm{H}_{\mathrm{B}}$ ), 6.51, 6.52, 6.54, 6.54 (each s, HHDP), 6.64, 6.65, 6.66, 6.66 (each s, val $\mathrm{H}_{\mathrm{A}}$ ), $6.69,6.69,6.69,6.71$ (each s, HHDP), 6.84, 6.90, 6.92, 6.95 (each s, galloyl 2H), 7.03-7.13 (each s, $2 \times$ galloyl $2 \mathrm{H}$, val $\mathrm{H}_{\mathrm{C}}$ )

${ }^{13} \mathrm{C}-\mathrm{NMR}\left(150 \mathrm{MHz}\right.$, Acetone- $\left.d_{6}+\mathrm{D}_{2} \mathrm{O}\right): \delta 62.7-63.2\left(\mathrm{C}-6_{\mathrm{R}}\right.$ and $\mathrm{C}-6_{\mathrm{L}}$ of each four form), 66.1-66.2 (C-5 $5_{R}$ of $\alpha-\alpha$ form, $C-5_{L}$ of $\alpha-\alpha$ form, $C-5_{L}$ of $\alpha-\beta$ form, $C-5_{R}$ of $\beta-\alpha$ form), 72.5-73.5 (C-3 ${ }_{R}$ of $\alpha-\beta$ form, $C-3_{L}$ of $\beta-\alpha$ form, $C-3_{R}$ of $\beta-\beta$ form, $C-3_{L}$ of $\beta-\beta$ form; $C-2_{R}$ of $\alpha-\beta$ form, $C-2_{L}$ of $\beta-\alpha$ form, $C-2_{R}$ of $\beta-\beta$ form, $C-2_{L}$ of $\beta-\beta$ form), 70.2-71.1 (C-4 ${ }_{L}$ of each four form, $C-4_{R}$ of each four form; $C-3_{R}$ of $\alpha-\alpha$ form, $C-3_{L}$ of $\alpha-\alpha$ form, $C-3_{L}$ of $\alpha-\beta$ form, $C-3_{R}$ of $\beta-\alpha$ form; $C-5_{R}$ of $\alpha-\beta$ form, $C-5_{L}$ of $\beta-\alpha$ form, $C-5_{R}$ of $\beta-\beta$ form, $C-5_{L}$ of $\beta-\beta$ form), 72.1-72.3 (C-2 ${ }_{R}$ of $\alpha-\alpha$ form, C- $2_{L}$ of $\alpha-\alpha$ form, $C-2_{L}$ of $\alpha-\beta$ form, C- $2_{R}$ of $\beta-\alpha$ form), 90.1-90.3 (C-1 $1_{R}$ of $\alpha-\alpha$ form, $C-1_{L}$ of $\alpha-\alpha$ form, $C-1_{L}$ of $\alpha-\beta$ form, $C-1_{R}$ of $\beta-\alpha$ form), 95.3-95.4 (C-1 $1_{R}$ of $\alpha-\beta$ form, $C-1_{L}$ of $\beta-\alpha$ form, $C-1_{R}$ of $\beta-\beta$ form, $C-1_{L}$ of $\beta-\beta$ form $), 104.2-$ 104.4 (val C-3' $)$, 106.8-107.0 (val C-3, HHDP C-3, HHDP C-3'), 109.1-109.4 (gal C-2 gal C-6; val C-6" $\left.{ }^{\prime \prime}\right), 113.2-115.3$ (HHDP C-1, HHDP C-1'; val C-1, val C-1" $)$, 116.5 116.7 (val C-1'), 119.6 120.1 (gal C-1), 124.6-125.6 (HHDP C-2, HHDP C-2'; val C-2, val C-2'), 135.1-136.8 (HHDP-5, HHDP-5'; val C-5, val C-5' , val-2"'), 138.2-138.4 (gal C-4), 139.3-139.8 (val C-3"', val C-4 ${ }^{\prime \prime}$ ), 142.3-142.5 (val C-5"'), 143.6-145.1 (gal C-3, gal C-5; HHDP C-4, HHDP C-4', HHDP C-6, HHDP C-6'; val C-4, val C-6, val C-6' ), 145.7-146.5 (val C-4' ), 163.8-166.2 (gal C-7), 166.8-168.1 (HHDP C-7, HHDP C-7'; val C-7, val C-7' val C-7"').

\subsection{Cell Culture}

Murine macrophage RAW 264.7 cells were purchased from the Korean Cell Line Bank (Seoul, Korea). These cells were grown at $37{ }^{\circ} \mathrm{C}$ in a humidified atmosphere $\left(5 \% \mathrm{CO}_{2}\right)$ in Dulbecco's Modified Eagle's Medium (DMEM; Sigma-Aldrich, St. Louis, MO, USA), supplemented with $10 \%$ fetal bovine serum (FBS), $100 \mathrm{IU} / \mathrm{mL}$ penicillin $\mathrm{G}$, and $100 \mathrm{mg} / \mathrm{mL}$ streptomycin (Gibco BRL, Grand Island, NY, USA). The cells were used after counting, using a hemocytometer. Human monocytic leukemia THP-1 cells purchased from the Korean Cell Line Bank were grown at $37^{\circ} \mathrm{C}$ in a humidified atmosphere $\left(5 \% \mathrm{CO}_{2}\right)$, in an RPMI 1640 medium (Sigma-Aldrich) supplemented with 10\% FBS and $100 \mathrm{IU} / \mathrm{mL}$ penicillin G (Thermo Fisher Scientific Korea Ltd., Seoul, Korea). These were used after counting, using a hemocytometer.

\subsection{Measurement of Cytokines Production}

The concentrations of cytokines (IL- $1 \beta$, IL- 6 , IL- 8 , and TNF- $\alpha$ in the culture supernatants were measured by an enzyme-linked immunosorbent assay (ELISA; eBioscience, San Diego, CA, USA). The cytokine concentrations were quantified by measuring the absorbance of the samples at $405 \mathrm{~nm}$ with an ELISA reader (TECAN). The levels of cytokines produced were calculated using a standard calibration curve. After the THP-1 cells were exposed to LPS, the cytokine levels were measured to determine the inhibitory effect of the compounds ( $\mathbf{1}$ and $\mathbf{2}$ ), which were used at a concentration $25 \mu \mathrm{M}$. 


\subsection{Apoptosis Activity}

Cells $(2 \times 105$ cells/well) were cultured in a 6-well plate for $24 \mathrm{~h}$, and then, treated with compounds 1 or $2(50 \mu \mathrm{M})$. The cells were then harvested and washed once using ice-cold PBS, after which they were resuspended in a binding buffer, and stained with $5 \mu \mathrm{L}$ Annexin V-FITC and $5 \mu \mathrm{L}$ of PI, for $15 \mathrm{~min}$, in the dark, at room temperature. The fluorescence was analyzed by flow cytometry (BD-LSR II, San Jose, CA, USA) using the "Cell Quest 2.0" software. At least 10,000 events were recorded and represented as dot plots. The percentage of cells in the upper left (necrotic cells), upper right (late apoptotic cells), lower right (early apoptotic cells), and lower left (viable cells) portion of the histogram was calculated for comparison.

\subsection{Measurement of Inhibitory $5 \alpha$-Reductase Activity}

The $5 \alpha$-reductase enzyme from rat liver microsomes was incubated with $400 \mu \mathrm{L}$ of phosphate buffer (pH 6.5) in the Intact group, and $200 \mu \mathrm{L}$ of phosphate buffer in the normal group (negative control). Testosterone was used as a substrate for $5 \alpha$-reductase at a volume of $50 \mu \mathrm{L}(100 \mu \mathrm{g} / \mathrm{mL})$. The other samples were incubated with $200 \mu \mathrm{L}(1 \mathrm{mM})$ of finasteride, which was considered the positive control group (finasteride), or $200 \mu \mathrm{L}$ $(1 \mathrm{mM})$ of compounds (1 and 2). Finally, $20 \mu \mathrm{L}$ of NADPH $(0.8 \mathrm{mg} / \mathrm{mL})$ was added. Microsomal enzymes ( $5 \alpha$-reductase) isolated from rat livers were added to the samples from all groups, except for the intact group. The reaction was terminated by adding $0.5 \mathrm{~mL}$ of dichloromethane for all group. The amount of testosterone in the samples was measured by HPLC. The injection volume was $20 \mu \mathrm{L}$ and elution was performed at a flow rate of $1 \mathrm{~mL} / \mathrm{min}$, using a binary gradient of water $(\mathrm{A})$ and acetonitrile $(\mathrm{ACN})(\mathrm{B})$. The quantification wavelength of these chromatograms was set at $242 \mathrm{~nm}$, which was optimized for testosterone. The data were integrated using the Empower software system (Waters, Coastal, CT, USA).

\subsection{Macrophage Differentiation and Stimulation}

The mature macrophage-like state was induced by treating the THP-1 monocytes (105 cells $/ \mathrm{mL}$ ) for $48 \mathrm{~h}$ with $10 \mathrm{nmol}$ of 12-O-tetradecanoylphorbol-13-acetate (TPA; SigmaAldrich), in 24-well cell culture plates, with $1 \mathrm{~mL}$ of cell suspension in each well. Differentiated plastic-adherent cells were washed once with phosphate-buffered saline (PBS) and cultured in a fresh RPMI 1640 medium (Sigma-Aldrich) supplemented with 10\% FBS and $100 \mathrm{IU} / \mathrm{mL}$ penicillin G (Gibco BRL). Differentiated THP-1 cells were treated with the test samples and $0.1 \mu \mathrm{g} / \mathrm{mL}$ of LPS (Sigma-Aldrich) for $1 \mathrm{~h}$ at $37^{\circ} \mathrm{C}$, in a humidified atmosphere $\left(5 \% \mathrm{CO}_{2}\right)$. After further incubation for $24 \mathrm{~h}$, the supernatants were transferred to Eppendorf tubes, for cytokine assays.

\subsection{Preparation of Liver Microsomes}

Liver microsomes were prepared from the liver of male rats. Two mature SpragueDawley male rats were euthanized, and their livers were removed and minced in a beaker, with a pair of scissors. The minced tissue was homogenized in three volumes of medium A (0.32 $\mathrm{M}$ sucrose, $1 \mathrm{mM}$ dithiothreitol, and $20 \mathrm{mM}$ sodium phosphate, $\mathrm{pH}$ 6.5) and the homogenate was centrifuged at $10,000 \times g$ for $10 \mathrm{~min}$. The resulting pellet was washed with two volumes of medium A. The combined supernatant from the two centrifugations was suspended in $4 \mathrm{~mL}$ of medium $\mathrm{A}$, and the dispersion of the microsomes was achieved using a syringe with $18 \mathrm{G}, 23 \mathrm{G}$, and $25 \mathrm{G}$ needles, in succession. The microsome suspension was divided into aliquots and stored at $-80^{\circ} \mathrm{C}$. The microsomes were diluted with the medium just before use.

\subsection{Statistical Analyses}

The results were analyzed by one-way analysis of variance (ANOVA), followed by the Student-Newman-Keuls (S-N-K) test and one to one confrontation test, to determine the 
$t$-value and $p$-value, using the Statistical Package for the Social Sciences (SPSS) software pack (IBM, Armonk, NY, USA).

\section{Conclusions}

The two ellagitannins [camptothin B (1), cornusiin A (2)] were isolated from Cornus alba (CA). The two ellagitannins (1 and 2) showed potent inhibitions of cytokine (IL-6, IL-8, IL-1 $\beta$ and TNF- $\alpha$ ) production, as well as anti-proliferative activities against the RWPE-1 cell. Moreover, they were also shown to induce apoptosis in the cell and inhibit the $5 \alpha-$ reductase activity, as compared to finasteride. Hence, the ellagitannins ( $\mathbf{1}$ and $\mathbf{2}$ ) isolated from CA may be good candidates for the treatment of $\mathrm{BPH}$.

Author Contributions: Conceptualization, M.-W.L. and D.-H.P.; methodology, D.-H.P. and K.-H.P.; software, D.-H.P., K.-H.P., J.Y., M.-J.K., S.-E.Y., S.-H.L., H.-J.C., J.-W.K., J.-H.H., and K.-M.K.; formal analysis, D.-H.P. and K.-H.P.; investigation, D.-H.P. and K.-H.P.; resources, D.-H.P., K.-H.P., and M.-W.L.; writing — original draft preparation, D.-H.P. and K.-H.P.; writing-review and editing, D.-H.P. and M.-W.L.; supervision, M.-W.L.; project administration, M.-W.L.; funding acquisition, M.-W.L. All authors have read and agreed to the published version of the manuscript.

Funding: This research was funded by the 'R\&D Program for Forest Science Technology (Project No. 2020208A002022-BA01)' provided by the Korea Forest Service (Korea Forestry Promotion Institute).

Institutional Review Board Statement: Not applicable.

Informed Consent Statement: Not applicable.

Data Availability Statement: The data are available in this article. Please inquiries about the data of the thesis can be made via e-mail to mwlee@cau.ac.kr.

Conflicts of Interest: The authors declare no conflict of interest.

Sample Availability: Samples of the compounds are not available from the authors.

\section{References}

1. Hong, S.J. Benign prostatic hyperplasia: Multiple factors for prostate tissue change with aging. Korean J. Urol. 2005, 46, 547-554.

2. Lee, E.H.; Chun, K.H.; Lee, Y.H. Benign Prostatic Hyperplasia in Community-Dwelling Elderly in Korea. J. Korean Acad. Nurs. 2005, 35, 1508-1513. [CrossRef]

3. Salinas-Sánchez, A.S.; Hernández-Millán, I.; Lorenzo-Romero, J.G.; Segura-Martín, M.; Fernández-Olano, C.; Virseda-Rodriguez, J.A. Quality of life of patients on the waiting list for benign prostatic hyperplasia surgery. Qual. Life Res. 2001, 10, 543-553. [CrossRef]

4. Kim, E.H.; Larson, J.A.; Andriole, G.L. Management of Benign Prostatic Hyperplasia. Annu. Rev. Med. 2016, 67, 137-151. [CrossRef]

5. Guess, H.; Arrighi, H.; Metter, E.; Fozard, J. Cumulative Prevalence of Prostatism Matches the Autopsy Prevalence of Benign Prostatic Hyperplasia. Prostate 1990, 17, 241-246. [CrossRef]

6. Marcelli, M.; Cunningham, G.R. Hormonal Signaling in Prostatic Hyperplasia and Neoplasia. J. Clin. Endocrinol. Metab. 1999, 84, 3463-3468. [CrossRef]

7. Thompson, T.C.; Yang, G. Regulation of Apoptosis in Prostatic Disease. Prostate 2000, 45, 25-28. [CrossRef]

8. Kapoor, A. Benign prostatic hyperplasia (BPH) management in the primary care setting. Can. J. Urol. 2012, 19, 10-17.

9. Chaim, M.; Wendy, V.H.; Hadas, D.F. Association Between Tamsulosin and Serious Opthalmic Adverse Events in Older Men Folowing Cataract Surgery. JAMA 2009, 301, 1991-1996. [CrossRef]

10. Kevin, T.M. A Review of Combination Therapy in Patients with Benign Prostatic Hyperplasis. Clin. Ther. 2007, 29, 387-398. [CrossRef]

11. Popovic, B.M.; Stajner, D.; Slavko, K.; Sandra, B. Antioxidant capacity of cornelian cherry (Cornus mas L.) -Comparison between permanganate reducing antioxidant capacity and other antioxidant methods. Food Chem. 2012, 134, 734-741. [CrossRef] [PubMed]

12. Polat, R.; Cakilcioglu, U.; Satil, F. Traditional uses of medicinal plants in Solhan (Bingöl-Turkey). J. Ethnopharmacol. 2013, 148, 951-963. [CrossRef]

13. Seeram, N.P.; Schutzki, R.; Chandra, A.; Nair, M.G. Characterization, Quantification, and Bioactivities of Anthocyanins in Cornus Species. J. Agric. Food Chem. 2002, 50, 2519-2523. [CrossRef]

14. Vareed, S.K.; Reddy, M.K.; Schutzki, R.E.; Nair, M.G. Anthocyanins in Cornus alternifolia, Cornus controversa, Cornus kousa and Cornus florida fruits with health benefits. Life Sci. 2006, 78, 777-784. [CrossRef] [PubMed]

15. Park, K.H.; Yin, J.; Yoon, K.H.; Hwang, Y.J.; Lee, M.W. Antiproliferative effects of new Dimeric Ellagitannin from Cornus alba in prostate cancer cells including apoptosis-related S-phase arrest. Molecules 2016, 21, 137. [CrossRef] [PubMed] 
16. Park, K.H. Anti-Proliferative Effects of Hydrolysable Tannins from Cornus alba; Chung-Ang University: Seoul, Korea; Korea Education and Research Information Service (KERIS): Daegu, Korea, 2013.

17. Giri, D.; Ozen, M.; Ittmann, M. Interleukin-6 is an Autocrine Growth Factor in Human Prostate Cancer. Am. J. Pathol. 2001, 159, 2159-2165. [CrossRef]

18. Hobisch, A.; Eder, I.E.; Putz, T.; Horninger, W.; Bartsch, G.; Klocker, H.; Culig, Z. Interleukin-6 Regulates Prostate-Specific Protein Expression in Prostate Carcinoma Cells by Activation of the Androgen Receptor. Cancer Res. 1998, 58, 4640-4645. [PubMed]

19. Nadler, R.B.; Koch, A.E.; Calhoun, E.A.; Campbell, P.L.; Pruden, D.L.; Bennett, C.L.; Yarnold, P.R.; Schaeffer, A.J. IL-1 $\beta$ and TNF- $\alpha$ in Prostatic Secretions are Indicators in the Evaluation of Men with Chronic Prostatitis. J. Urol 2000, 164, 214-218. [CrossRef]

20. De Nunzio, C.; Kramer, G.; Marberger, M.; Montironi, R.; Nelson, W.; Schröder, F.; Sciarra, A.; Tubaro, A. The Controversial Relationship between Benign Prostatic Hyperplasia and Prostate Cancer: The Role of Inflammation. Eur. Urol 2011, 60, 106-117. [CrossRef] [PubMed]

21. Jang, M.K.; Sohn, D.H.; Ryu, J. A Curcuminoid and Sesquiterpenes as Inhibitors of Macrophage TNF- $\alpha$ Release from Curcuma Zedoaria. Planta Med. 2001, 67, 550-552. [CrossRef] [PubMed]

22. Fadok, V.A.; Voelker, D.R.; Campbell, J.J.; Cohen, D.L.B.; Henson, P.M. Exposure of phosphatidylserine on the surface of apoptotic lymphocytes triggers specific recognition and removal by macrophages. J. Immunol. 1992, 148, 2207-2216.

23. Andree, H.A.; Reutelingsperger, C.P.; Hauptmann, R.; Hemker, H.C.; Hermens, W.T.; Willems, G.M. Binding of vascular anticoagulant alpha (VAC alpha) to planar phospholipid bilayers. J. Biol. Chem. 1990, 265, 4923-4928. [CrossRef]

24. Kim, E.H.; Brockman, J.A.; Andriole, G.L. The use of 5-alpha reductase inhibitors in the treatment of benign prostatic hyperplasia. Asian J. Urol. 2018, 5, 28-32. [CrossRef] [PubMed]

25. Arrigo, F.G.C.; Olta, A.; Gian, M.B.; Tommaso, C.; Gaetano, L.; Vittorio, M.; Gianpaolo, P.; Francesco, S.R.D.C.; Giorgio, I.R.; Kostantionos, S.; et al. Nutraceutical treatment and prevention of benign prostatic hyperplasia and prostate cancer. Arch. Ital. Urol. Androl. 2019, 91. [CrossRef]

26. Casciola-Rosen, L.; Rosen, A.; Petri, M.; Schlissel, M. Surface Blebs on Apoptotic Cells are Sites of Enhanced Procoagulant Activity: Implications for Coagulation Events and Antigenic Spread in Systemic Lupus Erythematosus. Proc. Natl. Acad. Sci. USA 1996, 93, 1624-1629. [CrossRef]

27. Engeland, M.; Ramaekers, F.C.; Schutte, B.; Reutelingsperger, C.P. A Novel Assay to Measure Loss of Plasma Membrane Asymmetry during Apoptosis of Adherent Cells in Culture. Cytom. J. Int. Soc. Anal. Cytol. 1996, 24, 131-139. [CrossRef]

28. Vermes, I.; Haanen, C.; Steffens-Nakken, H.; Reutellingsperger, C. A Novel Assay for Apoptosis Flow Cytometric Detection of Phosphatidylserine Expression on Early Apoptotic Cells using Fluorescein Labelled Annexin V. J. Immunol. Methods 1995, 184, 39-51. [CrossRef]

29. Askew, E.B.; Gampe Jr, R.T.; Stanley, T.B.; Faggart, J.L.; Wilson, E.M. Modulation of Androgen Receptor Activation Function 2 by Testosterone and Dihydrotestosterone. J. Biol. Chem. 2007, 282, 25801-25816. [CrossRef] [PubMed]

30. Wilbert, D.M.; Griffin, J.E.; Wilson, J.D. Characterization of the Cytosol Androgen Receptor of the Human Prostate. J. Clin. Endocrinol. Metab. 1983, 56, 113-120. [CrossRef] [PubMed]

31. Kovacs, W.J.; Griffin, J.E.; Weaver, D.D.; Carlson, B.R.; Wilson, J.D. A mutation that causes lability of the androgen receptor under conditions that normally promote transformation to the DNA-binding state. The J. Clin. Investig. 1984, 73, 1095-1104. [CrossRef] 